Preprint of Carr, Patrick L., Williams, Virginia Kay, and Jones, Mary Ann. (2007). Maximizing Access Through Consortial Partnership: Mississippi State University Libraries' Journal Expansion Project. Serials Review 33 (4): 215-223.

Note: This preprint does not include formatting, tables, or figures that appear in the published version.

\title{
MAXIMIZING ACCESS THROUGH CONSORTIAL PARTNERSHIP: MISSISSIPPI STATE UNIVERSITY LIBRARIES' JOURNAL EXPANSION PROJECT \\ BY
}

Patrick L. Carr, Assistant Professor/Coordinator of Serials, Mississippi State University Libraries; Virginia Kay Williams, Assistant Professor/Coordinator of Acquisitions, Mississippi State University Libraries; Mary Ann Jones, Assistant Professor/Electronic Serials Librarian, Mississippi State University Libraries,

\begin{abstract}
Consortial licenses with online access clauses can offer libraries the opportunity to begin new journal subscriptions at no additional cost and without losing access to existing subscriptions. Mississippi State University (MSU) participates in consortial partnerships that provide online access to all Elsevier and Wiley journals to which any partner subscribes. The license agreements prohibit simply canceling duplicate subscriptions, but allow any library to swap existing subscriptions for titles of equal cost. In 2006, librarians realized MSU was paying for access that it would retain regardless of whether it maintained subscriptions because many subscriptions were duplicated with partner libraries. This article describes a project that allowed MSU to provide online access to an additional 60 journals at no additional cost.
\end{abstract}

\section{INTRODUCTION}

Academic libraries currently exist in an environment of stagnant funding, inflating subscription costs, and growing expectations among users for immediate and seamless e-journal access. In such an environment, it is clear that no library is an island. Indeed, libraries' acquisition strategies increasingly reflect the realization that successfully meeting users' expectations requires an investment in consortial partnerships for e-journal access. While these partnerships vary in their size, structure, and organizational affiliations, they are generally created to collaborate and present a larger organization with more "buying power." This article provides a case study of how a library can take full advantage of its consortial partnerships. Specifically, it describes and analyzes how Mississippi State University Libraries carried out an innovative project of subscription de-duplication utilizing consortial partnerships to expand users' online access to journals published by Elsevier and John Wiley and Sons, Inc.

\section{LITERATURE REVIEW}

The project described in this article is best understood within the context of the professional discourse that has developed concerning consortial partnerships among libraries. A ten-year review of the library literature reveals numerous articles dealing with such topics as consortia management, the history of library consortia, the reasons for joining a consortium, and cost-benefit analyses of consortial partnerships. However, case studies such as the one detailed in this article, which focuses on libraries' cooperative development of e-journal collections, are scarce.

Historically, libraries have cooperated on many different levels. In the 1980s and 1990s there was an explosion of library consortia built around automation efforts and shared catalogs.1 With the growth of the Internet and networking capabilities, however, libraries are now able to share more than just 
reciprocal borrowing privileges and bibliographic information. As a result, the possibilities for partnership have become endless, and sharing is less restricted by geographic barriers. One way in which consortial partnerships have broadened in scope is by partnering to address the challenges of tightened budgets and increasing demand for e-journals through the negotiation and acquisition of e-journal packages. For example, Tim Bucknall2 describes how the Carolina Consortium was developed to enable 38 libraries in North and South Carolina to gain online access to e-journal packages offered by Blackwell, Springer, and Wiley without significant increases in the libraries' subscription costs. Likewise, Amy Brunvand, Daniel R. Lee, and Kathleen M. McCloskeyz discuss how the Utah Academic Library Consortium substantially expanded its ability to acquire e-journals when in 1997 the Utah legislature appropriated \$3.1 million to fund a proposal specifically addressing libraries' need to avoid the duplication of journal holdings. A third instance of how libraries have partnered to acquire e-journals is evident in David F. Kohl and Tom Sanville's 4 discussion of the OhioLINK library consortium. Expounding on the advantages of consortia big deal negotiating power, the authors describe how OhioLINK's "bulk buying" has resulted in expanded e-journal access for Ohio libraries.

Although consortial purchasing of e-journals is now widely practiced across the United States, a comprehensive review of the past ten years of the professional literature did not uncover a single article describing a project to expand a library's e-journal access by swapping duplicated consortial subscriptions for new titles. This case study suggests a strategy that individual libraries may use to increase e-journal access by taking full advantage of consortial partnerships.

\section{BACKGROUND}

Mississippi State University (MSU) is a public institution of higher education located in Starkville, Mississippi. Since its founding in 1864, MSU has grown to become a center for research and learning in the Southeast and currently holds a Carnegie Classification of RU/H: Research Universities (high research activity). As a comprehensive, land-grant university, MSU offers Doctoral and Master degree-granting programs is a wide array of disciplines while placing a particular emphasis on programs related to the life sciences and engineering. The primary information centers supporting the research and educational needs of the university's approximately 16,200 students and 1,200 faculty are the MSU Libraries, which currently provide users with online and/or print access to over 35,000 serial publications (this count includes titles accessible through aggregated full-text databases). One important means through which the Libraries are able to achieve this level of access in the face of stagnant funding and inflating subscription costs is consortial partnerships. Among these partnerships are two that are directly relevant to this case study: the EPSCoR Science Information Group (ESIG) and the Mississippi Elsevier Consortium (MEC).

\section{The EPSCoR Science Information Group (ESIG)}

ESIG is a consortium of libraries from the 27 states and territories participating in the National Science Foundation's Experimental Program to Stimulate Competitive Research (EPSCoR). EPSCoR's mission is to assist states traditionally not well funded for science and engineering research and to help "avoid undue concentration of such research and education." 5 ESIG was formed in 2001 after a proposal was submitted to the EPSCoR state directors identifying the need for information resources to sustain the research and education supported by the program. As described on its website, the goal of ESIG is to "enable participating libraries to better provide STM information to their researchers..."6 Central to achieving this goal is the development of license agreements with publishers that will enable participating libraries to expand users' journal access and/or decrease subscription costs. ESIG is administered by a board of directors who are elected to represent ESIG members; however, ESIG contracts with an agent to negotiate with publishers, administer the licensing process, and invoice for resources.

Because Mississippi is an EPSCoR eligible state, MSU was among the charter institutions of ESIG. Among the publishers that hold ESIG licensing agreements is Wiley. Established in 2002 and renewed for a three-year term in 2005, ESIG's license agreement with Wiley stipulates that all 14 libraries currently participating in the agreement are granted online access (1996 to present) to the Wiley 
journals to which any one of these libraries maintains a current online subscription.

\section{The Mississippi Elsevier Consortium (MEC)}

MEC was established in 2006 when a five-year license agreement took effect between Elsevier and the libraries at Mississippi's three largest academic institutions: MSU, the University of Mississippi, and the University of Southern Mississippi. Like the ESIG agreement with Wiley, MEC's agreement with Elsevier stipulates that all three libraries participating in the agreement are granted online access (1995 to present) to the Elsevier journals to which any one of these libraries maintains a current online subscription.

\section{THE JOURNAL EXPANSION PROJECT}

Following MSU's entry into the Elsevier and Wiley license agreements, numerous cases existed in which more than one of the partner libraries maintained current online subscriptions to the same Elsevier or Wiley journal. Partner libraries duplicated 125 of MSU's 406 Elsevier subscriptions and 78 of MSU's 93 Wiley subscriptions. The implication of this was that, as long as partner library maintained subscriptions, MSU was paying for access it would retain throughout the duration of the agreements regardless of whether it maintained its subscriptions. For example, one Wiley journal with a subscription cost exceeding $\$ 10,000$ was being subscribed to by nine ESIG libraries even though a single subscription was sufficient to provide access to the entire consortium. The license agreements prohibited libraries from dropping subscriptions to save money, but allowed them to swap titles in each package. In other words, a library could cancel its subscription to a journal in one of the agreements if it began new subscriptions to other journals by the publisher that had a total cost at least equal to the cost of the cancelled journal. MSU librarians realized that these licensing terms presented an opportunity to significantly expand journal access without an attendant increase in subscription costs.

In Fall 2005, the Associate Dean for Technical Services proposed the Journal Expansion Project (JExP) to the MSU Libraries' administrative council. The project would involve careful analysis of MSU's Elsevier and Wiley subscriptions to identify potential swaps, close collaboration with users to determine new titles of interest, and coordination with partner libraries to maximize access for all library users in the ESIG and MEC consortiums. The administrative council agreed that JExP was an opportunity to improve access for the MSU community while acting in the spirit of consortial partnership. A small team, consisting of the Associate Dean for Technical Services, Assistant Collection Development Officer, Electronic Serials Librarian, and Serials Librarian spearheaded the project.

\section{Planning and Data Collection}

Full scale planning for the JExP began in January 2006. The JExP team's strategy was based on the existing library liaison/representative program and a Filemaker Pro database containing records for each of MSU's approximately five thousand journal subscriptions. The library liaison/representative program is the primary channel of communication between the library and departments. Librarians serving as liaisons to departments and department faculty representatives collaborate on collection development projects. The Filemaker database, co-maintained by MSU's Collection Development and Serials units, includes bibliographic data, pricing information, usage statistics, and department coding. Departmental codes were assigned for previous projects based on librarians' judgment of which department relied most heavily on a journal to support the research and teaching of its faculty. The JExP team used the liaison/representative program and Filemaker database to inform departments of the opportunity to swap titles by identifying the duplicated Elsevier and Wiley subscriptions that they would be willing to cancel in order to gain online access to other Elsevier and Wiley journals. In order for the departments to make these assessments, the JExP team needed to supply each department with two lists of Elsevier and Wiley journals:

1. those that are assigned to the department and also subscribed to by at least one other partner library; and

2. those that are not subscribed to by any of the partner libraries but that would potentially support 
the department's research and teaching.

To generate the first list of Elsevier and Wiley journals, MSU's duplicated subscriptions, the JExP team relied upon publisher-supplied documents that listed each partner library's subscriptions. Using these documents, the JExP team determined if a MSU subscription was duplicated by a partner library and, if so, the number of partner libraries duplicating the subscription. The team next created fields within the Libraries' journal subscription database that could be used to store the information gathered and then supervised staff members' entry of data into these fields. In total, the JExP team identified 125 Elsevier subscriptions duplicated between MSU and at least one other MEC library and 70 Wiley subscriptions duplicated between MSU and at least one other ESIG library.

The second list of Elsevier and Wiley journals consisted of those that would potentially support a department's research and teaching but that were not subscribed to by any of the libraries participating in the license agreements. To generate this list, the JExP team first requested that Elsevier and Wiley supply them with spreadsheets of journals not subscribed to by MSU or any of its partner libraries. Next, the team used the subject headings provided in EBSCONET, the online subscription management system of MSU's subscription agent, in order to match the non-subscribed journals with the most relevant departments. The team did not have time to add additional data, such as interlibrary loan requests and ISI impact factors, to the non-subscribed title lists. Table 1 breaks down MSU's duplicated Elsevier and Wiley subscriptions by department and lists the number of non-subscribed journals that were matched to each of these departments.

\section{[Insert Table 1: MSU's Duplicated Subscriptions and Non-subscribed Journals By Department]}

Having generated the two journal lists described above, the JExP team next needed to determine what information about the journals on these lists the departments required to make informed decisions regarding subscription swaps. The data elements that the team ultimately decided to collect, as well as the sources for each of these elements, are indicated in Table 2. As the data for each journal was collected by staff members, it was entered into the appropriate database or spreadsheet fields. In the case of subscribed journals, these fields were located within the records of the Libraries' database of journal subscriptions. In the case of non-subscribed journals, these fields were cells within the spreadsheet that the JExP team used to match each non-subscribed journal with one or more relevant departments.

\section{[Insert Table 2: Data Elements Collected]}

After the JExP team had collected all of the information for subscription swaps, it needed to gather all of this information together so it could be presented to library liaisons and department representatives in a clear and organized manner. To do so, the team began by exporting information regarding the subscribed journals from the Libraries' database of journal subscriptions into a spreadsheet. From this master spreadsheet, each department's journals were pasted into a department-specific spreadsheet. The team also pasted the non-subscribed journals that had been matched to the department into this spreadsheet. The team formatted the data in each department's spreadsheet into three tabs. The first tab, titled "Guide," provided an introduction to the project as well as instructions and explanations of certain categories of data collected. The second and third tabs, titled "Elsevier" and "Wiley," listed a department's duplicated Elsevier and Wiley subscriptions along with the information that had been collected about these subscriptions. In addition, these tabs listed Elsevier and Wiley journals that are not subscribed to by any of the partner libraries but that could potentially support the department's research and teaching. Finally, these tabs featured a response section in which the departments were asked to indicate their swap recommendations. In the case of the "Wiley" tab, this response section also included an area asking if switching to online-only access (previously, the Libraries had been subscribing to Wiley journals online plus print at a deeply discounted price) was acceptable. The opportunity was also offered to select unsubscribed journals equivalent to the cost of any print they were willing to drop. Since the 
Libraries' Elsevier subscriptions were already online only, this section was not needed on the "Elsevier" tab. See Appendix A for an example of the spreadsheets distributed to departments.

\section{Outcome}

The departments' spreadsheets were presented to the library liaisons during a meeting in which the JExP team explained the project and answered liaisons' questions about what needed to be done to complete the project. Following this meeting, each liaison emailed his or her department's spreadsheet to the department representative. Although the department representatives were free to make swap recommendations using whatever procedures they preferred, the JExP team required that they submit these recommendations before the end of the Spring Semester. This deadline gave MSU time to review each department's recommendations and, upon approval by the Libraries' administrative council, communicate swap decisions to the publishers so that changes could take effect in 2007.

Table 3 summarizes department input on swaps. Seven of the 24 departments offered the opportunity to swap Elsevier journals agreed to do so, identifying 24 journals they would be willing to swap. These seven departments selected 36 journals to add. Because the total cost of the swapped out journals was less than the journals selected to add, the JExP team was able to add one additional Elsevier journal requested by a department that had not agreed to swap any journals. By swapping journals, the MSU Libraries were able to provide the MEC with online access to an additional 37 journals costing $\$ 76,122$ without additional expenditure. The Libraries' 70 duplicated Wiley subscriptions were coded to 21 departments. Of these departments, nine identified a total of 24 journals to swap; all of these departments used the cost savings from dropping print towards the cost of new journals. The departments recommended 23 journals costing $\$ 27,776$ to add.

\section{[Insert Table 3: Outcome of MSU's Journal Expansion Project]}

The JExP team emailed all partner libraries an explanation of the de-duplication project and a list of possible cancellations. The team asked that partner libraries review the proposed cancellation list and indicate any titles that the partners were considering dropping. Once these recommendations were reviewed and approved by the Libraries' administrative council, the JExP team sent out emails informing MSU's partner libraries in ESIG and MEC of the subscription swaps that MSU planned to make, asking the partner libraries to confirm they did not plan to drop any titles on the tentative drop list. The team had informed MEC partners of the project in advance, but did not inform ESIG partners in advance. Fortunately, no partner libraries were planning to drop titles on MSU's list, but the JExP team realizes they need to communicate with all partners before beginning similar projects in the future. Finally, the JExP team, via the Libraries' subscription agent, communicated MSU's swap decisions to Elsevier and Wiley. As planned, MSU's subscription swaps took effect in January 2007. Neither MSU or nor its partner libraries reported any problems accessing the journals swapped in the project.

\section{PROJECT EVALUATION}

Following the Libraries' receipt of swap recommendations from departments, the JExP team asked for feedback from the 31 department representatives and 16 library liaisons who participated in the project. Through this feedback, the team hoped to gain insights into such questions as how and why departments made swap recommendations, what difficulties representatives and liaisons had in completing the project, and how the Libraries could improve on future projects requiring departments to evaluate the Libraries' journal subscriptions. To acquire this feedback, the JExP team developed two webbased surveys, one for department representatives and the other for library liaisons. Requests to complete these surveys, which had been approved by MSU's Institutional Review Board for the Protection of Human Subjects in Research, were emailed to representatives and liaisons in the summer of 2006. 


\section{Survey of Department Representatives}

The JExP team's survey of department representatives was completed by 11 of the 31 representatives who participated in the project. The five questions on this survey, as well as a summary of responses, are provided in Table 4 . As this table shows, $81 \%$ of the respondents found the project to be at least somewhat valuable in enhancing their research and teaching. Four respondents (36\%) to the survey indicated that their departments recommended no changes. The most important factor influencing department decisions was the relevance of the unsubscribed journals to the faculty's research interests; $64 \%$ rated this factor very important. More than half of the respondents also indicated significant concerns about perpetual access and archival rights. To the JExP team's surprise, the least important factor in making decisions was usage statistics; only $27 \%$ of respondents indicated that usage statistics were important or very important. Seventy-three percent of department representatives reported that they asked all department faculty for input on the project while two representatives indicated that they made decisions on the department's behalf. The JExP team was concerned to note that two respondents were unsatisfied with the explanation provided for the project. One of the unsatisfied respondents commented that the department had not been aware that some journals were already online only, so would not trust the process and made no changes. On the other hand, three respondents made positive comments about the way the project was managed and about their library liaisons' explanations. The fifth comment was neutral, noting that the only journal the department had available to swap was tangential to their research interests.

\section{[Insert Table 4: Survey of Department Representatives]}

\section{Survey of Library Liaisons}

The JExP team's survey of library liaisons was completed by 13 of the 16 liaisons who participated in the project. The survey's four open-ended questions as well as summaries of responses to these questions are provided below.

Question 1: Were there any aspects of the project that confused you or that you feel should have been explained in more detail? If so, please discuss. Seven of the 13 librarians who responded to this question indicated that the project was clearly explained. Two noted that the information meeting in which the JExP team explained the project clarified their understanding of the spreadsheets. One commented on difficulty understanding the advantages and disadvantages of "print plus online" versus "online only" subscriptions. Three stated that they needed individual conferences with one of the JExP team members to understand exactly what they needed to do to complete the project.

Question 2: In your opinion, what could have been done differently in order to make the project less confusing for you and your department's faculty? Three of 12 librarians responded that no changes were needed. Three commented that the timing of the project was problematic and suggested that future projects be carried out earlier in the academic year. Two said that combining the Libraries' efforts to swap both Elsevier and Wiley subscriptions into a single project was confusing. Four made suggestions about improving instructions. These suggestions ranged from numbered step-by-step instructions to working through some concrete examples of how access would change if a subscription was swapped.

Question 3: What questions or concerns did your department's faculty express about the project? Seven of 12 librarians said no questions or concerns were expressed. The other five reported multiple concerns from their faculty. These concerns included:

$\square$ requests for more detailed pricing;

$\square$ unease about the project's timing;

fears that partner libraries might drop subscriptions;

$\square$ comments about departmental politics making it unwise to suggest dropping journals in one emphasis area when swap possibilities were in another area;

$\square$ a lack of awareness that many journals were already online only; and

$\square$ fears about losing access to cancelled journals if a consortium dissolved.

Question 4: Please provide any comments (positive or negative) about your perception of the 
Journal Expansion Project and how it could have been more effectively carried out. Three of the 10 librarians responding to this question reiterated their concerns about the timing of the project. Five made positive comments about the spreadsheets, informational meeting for liaisons, and assistance provided by members of the JExP team. One mentioned that a faculty member had been pleased that the spreadsheets were formatted for printing, as faculty seem more likely to respond to paper in departmental mailboxes than to email requests for input. Finally, one librarian suggested that future projects be explained at a meeting of library representatives and/or department heads with follow-up by liaisons to ensure that all departments receive the same information.

\section{CONCLUSION}

Overall, the MSU Libraries' Journal Expansion Project can be deemed a success. Charged by the Libraries' administrative council with the task of collaborating with library liaisons and department representatives in order to de-duplicate the Elsevier and Wiley subscriptions of partner libraries, the JExP team successfully planned and carried out a project that resulted in recommendations for subscription swaps being made by 10 of the 31 participating departments. Through these recommendations, MSU dropped subscriptions to 48 journals that were available from MEC and ESIG partner subscriptions and gained online access to 60 new journals at no additional cost.

In addition to expanding the journal access of MSU and its consortial partners, the JExP team gained valuable insights about how MSU's academic departments evaluate subscriptions and what librarians serving as liaisons find helpful in communicating with faculty. The concern faculty expressed about perpetual access encouraged the Serials unit to investigate e-journal archiving initiatives.

Comments on both liaison and department representative surveys indicated the importance of timing; the JExP team speculate that conducting the project late in the academic year may have discouraged some departments from swapping titles because faculty felt they lacked time to consider potential swaps. Drawing upon these insights, the Libraries will be equipped to plan future projects of journal evaluation in a manner that more effectively meets the needs of those participating in the projects.

There are a number of reasons why MSU's project of journal expansion should be of interest to other libraries who acquire e-journals through consortial partnerships. Of course, for libraries participating in consortial license agreements that give all partners access to any one partner's subscriptions, MSU's project provides a framework on which these libraries can model their own projects of subscription de-duplication. More broadly, the project provides an excellent example of how libraries can collaborate with users to maximize the resources they provide. With these efforts at innovation, however, comes a degree of risk. By de-duplicating its subscriptions, MSU has lost archival rights to the cancelled journals. Accordingly, if ESIG and MEC's license agreements are ever terminated, MSU's users may lose online access to the content of the cancelled journals. MSU's decision to proceed with the project despite these perils is reflective of the trend identified by Jim Stemper and Susan Barribeau in which most research libraries are willing to acquire e-resources even if they are not guaranteed perpetual access to those resources. Only time will tell whether the access MSU and its partner libraries have gained to Elsevier and Wiley journals outweigh the risks of losing perpetual access to cancelled subscriptions. At present, however, the Journal Expansion Project demonstrates how MSU is focusing on the existing needs of users in order to develop projects that take full advantage of its resources and partnerships, thereby continuing to thrive in an environment of growing user expectations and limited funds.

\section{NOTES}

1. Adrian W. Alexander, "Toward 'the Perfection of Work': Library Consortia in the Digital Age," Journal of Library Administration 28, no. 2 (1999): 1-14.

2. Tim Bucknall, “The Virtual Consortium,” Library Journal (Spring 2005): 16-18, 20.

3. Amy Brunvand, Daniel R. Lee, and Kathleen M. McCloskey, "Consortium Solutions to Distance Education Problems: Utah Academic Libraries Answer the Challenges," Journal of Library Administration 30, no. 3/4 (2001): 75-92.

4. David F. Kohl and Tom Sanville, "More Bang for the Buck: Increasing the Effectiveness of Library Expenditures through Cooperation," Library Trends 54 (2006): 394-410. 
5. National Science Foundation: Office of Integrative Activities, http://www.nsf.gov/od/oia/programs/epscor/about.jsp (accessed August 28, 2007).

6. EPSCoR Science Information Group, http://www.lib.montana.edu/ bmorton/esig/ (accessed July 8, 2007).

7. Jim Stemper and Susan Barribeau, "Perpetual Access to Electronic Journals: A Survey of One Academic Research Library's Licenses,” Library Resources \& Technical Services 50 (2006): 91-109. 